\title{
Sinorhizobium morelense sp. nov., a Leucaena leucocephala-associated bacterium that is highly resistant to multiple antibiotics
}

\author{
${ }^{1}$ Laboratorio de \\ Microbiología Agrícola, \\ Escuela Nacional de \\ Ciencias Biológicas, IPN, \\ Prol. de Carpio y Plan de \\ Ayala, 11340 México DF, \\ Mexico \\ 2 University of Bremen, \\ Faculty of Biology and \\ Chemistry, Laboratory of \\ General Microbiology, PO \\ Box 330440, D-28334 \\ Bremen, Germany \\ ${ }^{3}$ Laboratorium voor \\ Microbiologie, Vakgroep \\ Biochemie, Fysiologie en \\ Microbiologie, Universiteit \\ Gent, B-9000 Gent, \\ Belgium \\ ${ }^{4}$ Grupo de Ecología \\ Genética, Estación \\ Experimental del Zaidin, \\ CSIC, E-18008 Granada, \\ Spain \\ ${ }^{5}$ Centro de Investigación \\ sobre Fijación de \\ Nitrógeno, Universidad \\ Nacional Autónoma \\ de México, Apdo Postal \\ 565-A, Cuernavaca, \\ Morelos, Mexico
}

\author{
En Tao Wang, ${ }^{1,5}$ Zhi Yuan Tan, ${ }^{2}$ Anne Willems, ${ }^{3}$ Manuel Fernández- \\ López, ${ }^{4}$ Barbara Reinhold-Hurek ${ }^{2}$ and Esperanza Martínez-Romero ${ }^{5}$
}

Author for correspondence: En Tao Wang. Tel: + 5257296000 ext. 62385. Fax: + 5257296207.
e-mail: ewang@encb.ipn.mx

Sinorhizobium morelense sp. nov. is described to designate a group of bacteria isolated from root nodules of Leucaena leucocephala. S. morelense shows $98 \%$ $16 S$ rRNA gene sequence similarity to some Sinorhizobium species and to Ensifer adhaerens. This novel species is distinguished from other Sinorhizobium species and from $E$. adhaerens by DNA-DNA hybridization, 165 rRNA gene restriction fragments and sequence and some distinctive phenotypic features. Strains of this species are highly resistant to some antibiotics, such as carbenicillin (1 $\left.\mathrm{mg} \mathrm{ml}^{-1}\right)$, kanamycin $\left(500 \mu \mathrm{g} \mathrm{ml}^{-1}\right)$ and erythromycin $\left(300 \mu \mathrm{g} \mathrm{ml}^{-1}\right)$. They do not form nodules, but a nodulating strain, Lc57, is closely related to the novel species. Strain Lc04' (= LMG $21331^{\mathrm{T}}=$ CFN E1007') is designated as the type strain of this novel species.

Keywords: Sinorhizobium morelense, phylogeny, DNA-DNA relatedness, antibiotic resistance

\section{INTRODUCTION}

The soil bacteria within the genera Azorhizobium (Dreyfus et al., 1988), Allorhizobium (de Lajudie et al., 1998b), Bradyrhizobium (Jordan, 1982), Mesorhizobium (Jarvis et al., 1997), Rhizobium (Jordan, 1984) and Sinorhizobium (Chen et al., 1988; de Lajudie et al., 1994) are symbiotic nitrogen-fixers that form root and/or stem nodules on various leguminous plants. The taxonomy of these bacteria is currently under revision, and novel species are regularly being proposed (Amarger et al., 1997; van Berkum et al., 1998; Nick et al., 1999; Wang et al., 1998, 1999a). Close relationships between the rhizobia and non-nodulating bacteria have been reported, for example between Agrobacterium rhizogenes and Rhizobium tropici.

Using PCR-amplified 16S rRNA gene RFLP, multilocus enzyme electrophoresis (MLEE), cellular plas-

Abbreviation: MLEE, multi-locus enzyme electrophoresis.

The GenBank accession number for the 16S rRNA gene sequence of strain $\mathrm{LCO}^{\mathrm{T}}$ is AY024335. mid electrophoresis and nifH and nodDAB Southern hybridization, we have identified several genomic groups (rDNA types) among the rhizobial isolates associated with Leucaena leucocephala in Mexican soils (Wang et al., 1999b). One of these groups, rDNA type 11, was closely related to Rhizobium giardinii based on the analysis of RFLP patterns of PCRamplified 16S rRNA genes. Isolates of rDNA type 11 formed a minor proportion of the rhizobia from about $5 \%$ of the nodules of $L$. leucocephala. Since $R$. giardinii (Amarger et al., 1997) represents a phylogenetic branch that is distantly related to other Rhizobium species, we were interested in these $R$. giardinii-related bacteria. To verify the taxonomic and phylogenetic positions of this novel group, we characterized the isolates within the rDNA type 11 group further using 16S rRNA gene sequencing, DNA-DNA hybridization and phenotypic analysis. In this study, the phylogenetic relationships between rDNA type 11, Sinorhizobium species and Ensifer adhaerens were found to be closer than those between this novel group and $R$. giardinii. The DNA relatedness obtained from DNA-DNA hybridization and the phenotypic characterization indicated 
that the novel group was distinct from all Sinorhizobium species, $E$. adhaerens and $R$. giardinii and we therefore propose a novel species within the genus Sinorhizobium, Sinorhizobium morelense sp. nov., for this group.

\section{METHODS}

Isolates and strains. The bacteria used in this research are listed in Table 1. Since the isolates within rDNA type 11 were fast-growing, acid-producing rhizobia (Wang et al., 1999b), type strains of species within the genera Agrobacterium, Rhizobium and Sinorhizobium were included as references. All strains were kept in PY medium (peptone of casein, $5.0 \mathrm{~g}$; yeast extract, $3.0 \mathrm{~g}$; $\mathrm{CaCl}_{2}, 0.6 \mathrm{~g}$; distilled water, 11 ) at $4{ }^{\circ} \mathrm{C}$ for temporary storage and in $20 \%$ glycerol at $-20{ }^{\circ} \mathrm{C}$ for long-term storage.

Sequencing and phylogenetic analysis of 16S rRNA genes. Isolate $\mathrm{Lc} 4^{\mathrm{T}}$, representative of rDNA type 11, was used for $16 \mathrm{~S}$ rRNA gene sequencing using the method of direct sequencing from PCR products (Hurek et al., 1997). The sequence obtained was deposited in the GenBank database and was compared with related sequences from the database. The sequences were aligned using the PILEUP program in the Wisconsin package version 8.1 (Genetics Computer Group, 1995). A phylogenetic tree was reconstructed and bootstrapped with 1000 replications of each sequence using CLUSTAL W (Thompson et al., 1994). The tree was visualized by using the program TreeView (Page, 1996).

DNA-DNA hybridization and DNA base composition. DNA extraction and Southern hybridization were performed as described previously (Wang et al., 1998) to estimate the DNA-DNA relatedness among isolates of rDNA type 11 and the reference strains. For DNA-DNA hybridizations between strain ${\mathrm{Lc} 04^{\mathrm{T}}}$ and $E$. adhaerens strains, a microplate method modified from Ezaki et al. (1989) as described by Willems et al. (2001) was used, with hybridizations carried out at $45^{\circ} \mathrm{C}$. For determination of DNA base composition, DNA of strain ${\mathrm{Lc} 04^{\mathrm{T}}}$ was degraded enzymically into nucleosides as described by Mesbah et al. (1989). The resulting nucleoside mixtures were separated by HPLC using a Waters Symmetry Shield $\mathrm{C} 8$ column at $37^{\circ} \mathrm{C}$. The solvent was $0.02 \mathrm{M} \mathrm{NH}_{4} \mathrm{H}_{2} \mathrm{PO}_{4}(\mathrm{pH} 4.0)$ with $1.5 \%$ acetonitrile. Non-methylated lambda phage DNA (Sigma) was used as the calibration reference.

Phenotypic characterization. Methods described previously (Wang et al., 1998) were used to analyse the utilization of sole carbon and nitrogen sources, resistance to antibiotics, tolerance of $0.5-4.0 \%(\mathrm{w} / \mathrm{v}) \mathrm{NaCl}$, the $\mathrm{pH}$ and temperature ranges for growth and growth in LB medium and in litmus milk. Anaerobic growth by reduction of nitrate or sulfate was determined in YM broth supplemented with $6 \mathrm{mM}$ $\mathrm{K}_{2} \mathrm{NO}_{3}$ or $\mathrm{Na}_{2} \mathrm{SO}_{4}$ (Daniel et al., 1982). Gram staining and cellular morphology were examined using routine methods.

Nodulation tests. Cross-nodulation was performed using strains $\mathrm{Lc}^{\mathrm{T}}$, Lc18, Lc56a and Lc57 to inoculate $L$. leucocephala, Phaseolus vulgaris and Acacia farnesiana, as described by Vincent (1970).

\section{RESULTS AND DISCUSSION}

\section{Sequencing and phylogeny of 16S rRNA genes}

The 16S rRNA gene sequence obtained from Lc04 ${ }^{\mathrm{T}}$ was $1436 \mathrm{bp}$ long. According to the sequence analysis, isolate $\mathrm{Lc} 04^{\mathrm{T}}$ was most closely related to Sinorhizobium species. It had around $98 \%$ sequence identity to Sinorhizobium fredii, Sinorhizobium xinjiangense, Sinorhizobium meliloti and Sinorhizobium medicae and $97 \%$ sequence identity to the other Sinorhizobium species. E. adhaerens, a non-symbiotic soil bacterium (Casida, 1982), showed $98 \%$ sequence identity to isolate $\mathrm{Lc} 4^{\mathrm{T}}$. The sequence identity between Mesorhizobium species and isolate $\mathrm{Lc}^{\mathrm{T}} 4^{\mathrm{T}}$ ranged from 94 to

Table 1. Rhizobial isolates and strains used in this study

\begin{tabular}{|c|c|c|c|}
\hline Isolate or strain & Host plant & Geographical origin & Reference \\
\hline $\begin{array}{l}\text { rDNA type } 11 \text { (Sinorhizobium morelense sp. nov.) isolates } \\
\text { Lc04 }^{\mathrm{T}}, \mathrm{Lc} 18, \mathrm{Lc} 19, \mathrm{Lc} 21, \mathrm{Lc} 29, \mathrm{Lc} 44, \mathrm{Lc} 56 \mathrm{a}\end{array}$ & L. leucocephala & Mexico & Wang et al. (1999b) \\
\hline Other rDNA type 11 isolate Lc57 & L. leucocephala & Mexico & Wang et al. (1999b) \\
\hline \multicolumn{4}{|l|}{ Agrobacterium tumefaciens $\mathrm{HAMBI} 1811^{\mathrm{T}}$} \\
\hline \multicolumn{4}{|l|}{ Agrobacterium vitis $\mathrm{HAMBI} 1817^{\mathrm{T}}$} \\
\hline Ensifer adhaerens ATCC 33212 ${ }^{\mathrm{T}}$, ATCC 33499 & & & Balkwill (2002) \\
\hline Rhizobium gallicum $\mathrm{R} 602 \mathrm{sp}^{\mathrm{T}}$ & Phaseolus vulgaris & France & Amarger et al. (1997) \\
\hline Rhizobium giardinii $\mathrm{H} 152^{\mathrm{T}}$ & P. vulgaris & France & Amarger et al. (1997) \\
\hline Rhizobium leguminosarum USDA $2370^{\mathrm{T}}$ & Pisum sativum & USA & Jordan (1984) \\
\hline Rhizobium mongolense USDA $1844^{\mathrm{T}}$ & Medicago sp. & China & van Berkum et al. (1998) \\
\hline Rhizobium tropici CIAT $899^{\mathrm{T}}$ & L. leucocephala & Colombia & Martínez-Romero et al. (1991) \\
\hline \multicolumn{4}{|l|}{ Sinorhizobium arboris } \\
\hline HAMBI $1552^{\mathrm{T}}$ & Prosopis chilensis & Sudan & Nick et al. (1999) \\
\hline HАMBI 1396 & P. chilensis & Kenya & Nick et al. (1999) \\
\hline HAMBI 1700, HAMBI 1624 & Acacia senegal & Sudan & Nick et al. (1999) \\
\hline Sinorhizobium kostiense HAMBI 1489 ${ }^{\mathrm{T}}$, HAMBI 1501 & A. senegal & Sudan & Nick et al. (1999) \\
\hline Sinorhizobium fredii USDA $205^{\mathrm{T}}$, USDA 202, USDA 191 & Glycine $\max$ & China & Chen et al. (1988) \\
\hline \multicolumn{4}{|l|}{ Sinorhizobium medicae } \\
\hline $\mathrm{A} 320^{\mathrm{T}}$ & Medicago sp. & & Rome et al. (1996) \\
\hline $\mathrm{m} 75$ & & & Eardly et al. (1990) \\
\hline \multicolumn{4}{|l|}{ Sinorhizobium meliloti } \\
\hline USDA $1002^{\mathrm{T}}$ & Medicago sativa & & Jordan (1984) \\
\hline 74B12 & & & Eardly et al. (1990) \\
\hline Sinorhizobium saheli LMG 77837 ${ }^{\mathrm{T}}$, LMG 8310 , LMG 11864 & Sesbania sp. & Senegal & de Lajudie et al. (1994) \\
\hline Sinorhizobium terangae $\mathrm{LMG} 7834^{\mathrm{T}}$ & Acacia laeta & Senegal & de Lajudie et al. (1994) \\
\hline Sinorhizobium xinjiangense CCBAU $110^{\mathrm{T}}$, CCBAU $105, \mathrm{R} \times 41$ & G. $\max$ & China & Chen et al. (1988) \\
\hline
\end{tabular}




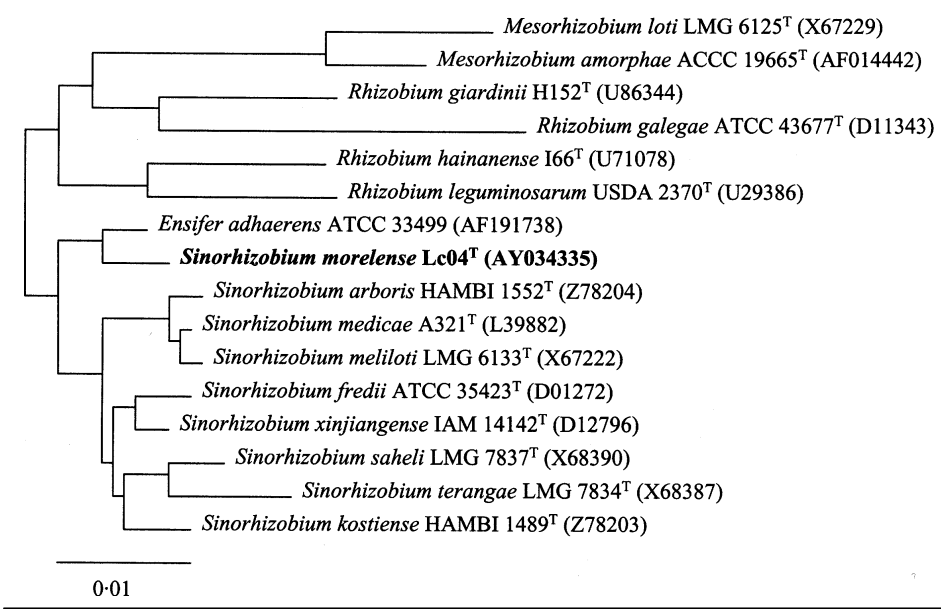

Fig. 1. Simplified phylogram of $16 \mathrm{~S}$ rRNA gene sequences obtained in this research and in GenBank showing the phylogenetic position of rDNA type 11, represented by isolate $\mathrm{LCO}^{\top}$. Sequences were aligned using the PILEUP program in the GCG package (Genetics Computer Group, 1995). CLUSTAL W (Thompson et al., 1994) was used to reconstruct the tree and bootstrap the tree from 1000 replications of the aligned sequences. Accession numbers of the nucleotide sequences are indicated in parentheses. Bar, $1 \%$ nucleotide substitution.

Table 2. DNA relatedness between isolate $\mathrm{LCO}^{\top}$ and other isolates of rDNA type 11 and reference strains

Values were obtained by Southern hybridization of total DNA unless indicated.

\begin{tabular}{|c|c|}
\hline Isolate or strain & $\begin{array}{l}\text { DNA relatedness }(\%) \\
\text { to isolate } \mathrm{Lc04}^{\mathrm{T}}\end{array}$ \\
\hline \multicolumn{2}{|l|}{ rDNA type11 } \\
\hline $\mathrm{Lc} 4^{\mathrm{T}}$ & 100 \\
\hline Lc18 & $80 \cdot 2 \pm 2 \cdot 4$ \\
\hline Lc57 & $79 \cdot 8$ \\
\hline Lc56a & $99 \cdot 2$ \\
\hline E. adhaerens ATCC $33212^{\mathrm{T}}$ & $41 *$ \\
\hline E. adhaerens ATCC 33499 & $39^{*}$ \\
\hline S. arboris LMG $1489^{\mathrm{T}}$ & $33 \cdot 6 \pm 12 \cdot 0$ \\
\hline S. kostiense LMG $1552^{\mathrm{T}}$ & $34 \cdot 5 \pm 3 \cdot 2$ \\
\hline S. fredii USDA $205^{\mathrm{T}}$ & $19 \cdot 3$ \\
\hline S. medicae USDA $1037^{\mathrm{T}}$ & $39 \cdot 0 \pm 0 \cdot 5$ \\
\hline S. meliloti USDA $1002^{\mathrm{T}}$ & $17 \cdot 5 \pm 1 \cdot 9$ \\
\hline S. saheli $\mathrm{LMG} 7837^{\mathrm{T}}$ & $31 \cdot 4 \pm 0 \cdot 6$ \\
\hline S. terangae LMG $7834^{\mathrm{T}}$ & $31 \cdot 4 \pm 0 \cdot 6$ \\
\hline S. xinjiangense CCBAU $110^{\mathrm{T}}$ & $27 \cdot 5 \pm 4 \cdot 8$ \\
\hline $\begin{array}{l}\text { Agrobacterium tumefaciens } \\
\text { HAMBI } 1811^{\mathrm{T}}\end{array}$ & $10 \cdot 8 \pm 1 \cdot 0$ \\
\hline Agrobacterium vitis HAMBI $1817^{\mathrm{T}}$ & $20 \cdot 8$ \\
\hline R. galegae USDA $4128^{\mathrm{T}}$ & $29 \cdot 2 \pm 8 \cdot 2$ \\
\hline R. gallicum $\mathrm{R} 603 \mathrm{sp}^{\mathrm{T}}$ & $12 \cdot 0 \pm 1 \cdot 1$ \\
\hline R. giardinii $\mathrm{H} 152^{\mathrm{T}}$ & $21 \cdot 5 \pm 3 \cdot 9$ \\
\hline R. leguminosarum USDA $2370^{\mathrm{T}}$ & $17 \cdot 2$ \\
\hline R. mongolense USDA $1844^{\mathrm{T}}$ & $18 \cdot 3$ \\
\hline R. tropici CIAT $899^{\mathrm{T}}$ & $18 \cdot 9 \pm 4 \cdot 8$ \\
\hline
\end{tabular}

* Value obtained using a microplate hybridization method.

$95 \%$. The sequence identity was $96 \%$ between isolate $\mathrm{Lc}^{\mathrm{T}}{ }^{\mathrm{T}}$ and $R$. giardinii and it was lower for other Rhizobium species. Isolate $\mathrm{Lc} 4^{\mathrm{T}}$ clustered with $E$. adhaerens in the reconstructed phylogenetic tree (Fig. 1). These two species formed the most divergent branch within the Sinorhizobium group. The phylogenetic relationships among the defined rhizobial species were similar in our reconstructed tree and previously published trees (e.g. de Lajudie et al., 1998a, b; Wang et al., 1999a). In contrast to the relationship estimated from 16S rRNA gene RFLP analysis (Wang et al., 1999b), isolates of rDNA type 11 were found to belong to the Sinorhizobium phylogenetic lineage on the basis of comparative analysis of $16 \mathrm{~S}$ rRNA gene sequences (Fig. 1). The different relationships revealed previously by PCR-RFLP and by sequencing analyses might indicate a limitation of PCR-RFLP analysis in accurate estimation of phylogenetic relationships. In Fig. 1, the close relationship between E. adhaerens, Sinorhizobium species and isolate $\mathrm{Lc04}^{\mathrm{T}}$ offered further evidence that the symbiotic species may have a common origin with non-symbiotic bacteria (Wang \& Martínez-Romero, 2000).

\section{DNA G + C content and DNA-DNA hybridization}

The DNA $\mathrm{G}+\mathrm{C}$ content of strain $\mathrm{Lc04}^{\mathrm{T}}$ was $61 \cdot 7$ $\mathrm{mol} \%$. The data for DNA-DNA relatedness obtained from hybridization are presented in Table 2 . The four representative isolates of rDNA type 11 had DNA relatedness of $79 \cdot 8-100 \%$. The values of DNA relatedness were $39-41 \%$ between the group 11 isolate $\mathrm{Lc}^{\mathrm{T}}{ }^{\mathrm{T}}$ and Ensifer strains, 17.5-39.0\% between isolate $\mathrm{Lc}^{\mathrm{T}}{ }^{\mathrm{T}}$ and type strains of Sinorhizobium species and 10.8$29.2 \%$ between isolate ${\mathrm{Lc} 04^{\mathrm{T}}}$ and the type strains of some Agrobacterium and Rhizobium species. Although the use of $70 \%$ DNA relatedness as a threshold for bacterial species has been seriously criticized (Ward, 1998), this criterion has been used in the description of many rhizobial species, such as Mesorhizobium ciceri (Nour et al., 1994) and Rhizobium hainanense (Chen et al., 1997). In this study, the large gap between the relatedness among rDNA type 11 isolates and that between this group and other species indicated that the isolates of rDNA type 11 represent a unique genomic species, different from the described species of the genera Ensifer, Rhizobium and Sinorhizobium. This conclusion was also supported by MLEE results reported previously (Wang et al., 1999b). 


\section{Phenotypic characterization}

A total of 113 phenotypic features was analysed for the isolates and reference strains. None of bacteria tested could use 2-anthranilic acid, benzoic acid, coumaric acid, fluorobenzoic acid, propionic acid or salicylic acid as sole carbon sources and all were sensitive to $1 \mathrm{mg}$ kanamycin $\mathrm{ml}^{-1}$ and $500 \mu \mathrm{g}$ neomycin $\mathrm{ml}^{-1}$. None could grow anaerobically in YM broth with or without sodium sulfate $(6 \mathrm{mM})$. All eight isolates could grow anaerobically in YM broth by denitrification. Isolate Lc57 was different in many aspects from the other seven isolates. The seven isolates were able to use most of the compounds tested, including sugars, organic acids, amino acids and alcohols, as sole carbon sources. However, they grew better and formed larger colonies with di- or trisaccharides (sucrose, lactose, maltose, melibiose, raffinose, trehalose or melezitose), organic acids and amino acids than with monosaccharides (such as fructose, glucose, fucose, xylose, glycerol or mannitol). They could use most of the amino acids, except DL-alanine and urea, as sole sources of nitrogen. Growth was improved by adding biotin as a growth factor in defined media and they grew in defined medium supplemented with hydrolytic casein as the sole carbon and nitrogen source. The seven isolates were resistant to $\left(\mu \mathrm{l}^{-1}\right) 1 \mathrm{mg}$ carbenicillin, $500 \mu \mathrm{g}$ kanamycin, $300 \mu \mathrm{g}$ erythromycin, $100 \mu \mathrm{g}$ neomycin and streptomycin and $5 \mu \mathrm{g}$ gentamicin and chloramphenicol, but sensitive to $5 \mu \mathrm{g}$ tetracycline and $20 \mu \mathrm{g}$ nalidixic acid $\mathrm{ml}^{-1}$. They could grow at $\mathrm{pH}$ $5.0-10.0$ and were tolerant of $2 \cdot 0 \%(\mathrm{w} / \mathrm{v}) \mathrm{NaCl}$. They could not grow at $37^{\circ} \mathrm{C}$. The generation time ranged from 1.5 to $2.0 \mathrm{~h}$. Multiplication by budding was observed in isolates $\mathrm{Lc}^{\mathrm{T}}{ }^{\mathrm{T}}$ and Lc18. These results implied that the seven isolates of rDNA type 11 were a group phenotypically different from other species. The distinctive features of rDNA type 11, E. adhaerens, Sinorhizobium species and $R$. giardinii are listed in Table 3.

\section{Nodulation tests}

Strains $\mathrm{Lc}^{\mathrm{T}}{ }^{\mathrm{T}}$, Lc18 and Lc56a were incapable of forming nodules on L. leucocephala, A. farnesiana or on $P$. vulgaris, while nodules were obtained on L. leucocephala plants inoculated with isolate Lc57. Bacteria isolated from the root nodules of some legume plants have been shown to be closely related to or to be member of the non-symbiotic genus Agrobacterium (Tan et al., 1999). Therefore, we postulate that the non-nodulating isolates in rDNA type 11 may, as has been reported for Agrobacterium strains, have simply entered the nodules opportunistically. Alternatively, the bacteria may have lost their symbiotic plasmid after isolation from nodules.

Based on all the data presented in this work and in our previous report (Wang et al., 1999b), it is clear that the non-nodulating strains in rDNA type 11 are a group related to the genera Sinorhizobium and Ensifer. Since this group is phylogenetically, genetically and pheno- typically distinct from the eight species within the genus Sinorhizobium, S. meliloti, Sinorhizobium saheli (de Lajudie et al., 1994), Sinorhizobium terangae (de Lajudie et al., 1994), S. medicae (Rome et al., 1996), Sinorhizobium fredii (Chen et al., 1988), S. xinjiangense (Chen et al., 1988), Sinorhizobium arboris (Nick et al., 1999) and Sinorhizobium kostiense (Nick et al., 1999), and different from Ensifer adhaerens (Casida, 1982), we conclude that rDNA type 11 is a novel species.

E. adhaerens is a Gram-negative soil bacterium that adheres to other bacteria and may cause their lysis (Casida, 1982). The 16S rRNA gene sequence of $E$. adhaerens revealed that it was related to Sinorhizobium, although it was considered to be outside this genus (Balkwill, 2002). We have shown elsewhere that $E$. adhaerens constitutes a group of non-nodulating bacteria that do not harbour nifH genes. Furthermore, it has been reported that E. adhaerens ATCC 33499 could be converted into a nitrogen-fixing symbiont by the introduction of the symbiotic plasmid from $R$. tropici to this bacterium (Rogel et al., 2001). The results of our own work indicate that there are both symbiotic and non-symbiotic strains in rDNA type 11, as reported for Rhizobium etli (Segovia et al., 1991). Collectively, all these data imply that Ensifer and Sinorhizobium could be seen as synonyms. The older name (Ensifer) would have priority over the younger one (Sinorhizobium). However, the community of users of rhizobial taxonomy will not welcome a change of Sinorhizobium to Ensifer and we therefore propose to describe rDNA group 11 as a novel species in Sinorhizobium. This synonymy of Sinorhizobium and Ensifer will be discussed in detail in a future manuscript.

In our previous work (Wang et al., 1999b), strain Lc57 was identified as type 11 since it had a 16S rRNA gene PCR-RFLP pattern identical to the other seven strains. In MLEE analysis, this strain had an electrophoretic type different from, but very similar to, that of the other seven strains (Wang et al., 1999b). However, strain Lc57 was quite different from the other seven strains in its phenotypic characters. It was sensitive to antibiotics that the other seven strains were resistant to. It had a slower growth rate. Colonies were $\leqslant 1 \mathrm{~mm}$ after 5 days incubation on PY medium and had less exopolysaccharide than those of the other seven isolates. Strains $\mathrm{Lc} 57$ and $\mathrm{Lc} 4^{\mathrm{T}}$ had $79 \cdot 8 \%$ DNADNA relatedness. We hesitated to include strain Lc57 in the same species as the other seven strains in view of these documented differences. Nevertheless, the close relationship between strain Lc57 and the non-nodulating strains in rDNA type 11 is further evidence that rhizobia may have a common ancestry with other bacteria.

Taking into consideration the data from our previous report (Wang et al., 1999b) and from this study, as well as the suggestions of Graham et al. (1991) and Wayne et al. (1987), we propose a novel species, Sinorhizobium morelense sp. nov., for the seven strains of rDNA type 11 from L. leucocephala. This is the fifth rhizobial species that is from leguminous trees in tropic regions. 
Table 3. Distinctive features of strains of rDNA type 11 and related species

Species are identified as: 1, E. adhaerens; 2, R. giardinii; 3, S. meliloti; 4, S. medicae; 5, S. fredii; 6, S. xinjiangense; 7, S. saheli; 8, S. terangae; 9, S. arboris; 10, S. kostiense. d, Variable; ND, no data available.

\begin{tabular}{|c|c|c|c|c|c|c|c|c|c|c|c|c|}
\hline \multirow[t]{2}{*}{ Characteristic } & \multicolumn{2}{|c|}{ rDNA type 11} & \multirow[t]{2}{*}{1} & \multirow[t]{2}{*}{2} & \multirow[t]{2}{*}{3} & \multirow[t]{2}{*}{4} & \multirow[t]{2}{*}{5} & \multirow[t]{2}{*}{6} & \multirow[t]{2}{*}{7} & \multirow[t]{2}{*}{8} & \multirow[t]{2}{*}{9} & \multirow[t]{2}{*}{10} \\
\hline & 7 strains & Lc57 & & & & & & & & & & \\
\hline Signature sequence in $16 \mathrm{~S}$ rRNA* & - & ND & + & - & - & - & - & - & - & - & - & - \\
\hline Division by budding & + & - & + & - & - & - & - & - & - & - & - & - \\
\hline Growth in LB & + & - & ND & - & + & + & $\mathrm{d}$ & - & - & + & + & - \\
\hline \multicolumn{13}{|l|}{ Tolerance of: } \\
\hline $2 \% \mathrm{NaCl}$ & + & - & + & + & + & + & $\mathrm{d}$ & - & - & + & + & - \\
\hline $2 \cdot 5 \% \mathrm{NaCl}$ & - & - & + & + & $\mathrm{d}$ & $\mathrm{d}$ & $\mathrm{d}$ & - & + & - & - & + \\
\hline \multicolumn{13}{|l|}{ Growth at: } \\
\hline $37^{\circ} \mathrm{C}$ & - & + & + & - & + & + & + & $\mathrm{d}$ & + & + & + & + \\
\hline $\mathrm{pH} 5 \cdot 0$ & + & - & ND & + & - & + & $\mathrm{d}$ & - & - & - & - & - \\
\hline $\mathrm{pH} 10 \cdot 0$ & + & - & $\mathrm{ND}$ & - & - & + & - & - & - & - & - & - \\
\hline Alkali production in litmus milk & - & + & ND & + & + & + & + & + & + & + & + & + \\
\hline Anaerobic growth by denitrification & + & + & + & - & $\mathrm{d}$ & - & - & + & - & + & $\mathrm{d}$ & - \\
\hline \multicolumn{13}{|l|}{ Utilization of sole carbon sources: } \\
\hline DL-Arabinose & - & + & ND & + & + & + & $\mathrm{d}$ & $\mathrm{d}$ & + & - & $\mathrm{d}$ & + \\
\hline Dulcitol & - & - & $\mathrm{ND}$ & + & $\mathrm{d}$ & - & - & - & - & - & + & - \\
\hline Inositol & - & + & ND & - & + & + & $\mathrm{d}$ & + & + & - & + & + \\
\hline Citrate & + & - & $\mathrm{ND}$ & + & - & - & $\mathrm{d}$ & - & - & - & - & - \\
\hline Glycine & + & - & $\mathrm{ND}$ & - & - & - & - & - & - & - & + & - \\
\hline L-Tryptophan & + & - & ND & - & - & - & - & - & - & - & + & - \\
\hline Acetate & + & - & + & - & - & - & $\mathrm{d}$ & - & + & - & - & - \\
\hline Arabitol & - & - & ND & + & + & + & $\mathrm{d}$ & $\mathrm{d}$ & - & + & + & + \\
\hline \multicolumn{13}{|l|}{ Resistance to antibiotics $\left(\mu \mathrm{g} \mathrm{ml}^{-1}\right)$ : } \\
\hline Carbenicillin (1000) & + & - & $\mathrm{ND}$ & - & - & - & - & - & - & - & - & - \\
\hline Kanamycin $(500)$ & + & - & ND & - & - & - & - & - & - & - & - & - \\
\hline Erythromycin (300) & + & - & $\mathrm{ND}$ & - & - & - & - & - & - & - & - & - \\
\hline Streptomycin (100) & + & - & ND & - & - & - & - & - & - & - & - & - \\
\hline Neomycin (100) & + & - & $\mathrm{ND}$ & - & - & - & - & - & - & - & - & - \\
\hline Gentamicin (5) & + & - & ND & - & + & + & $\mathrm{d}$ & - & - & + & + & $\mathrm{d}$ \\
\hline Nalidixic acid (20) & - & + & $\mathrm{ND}$ & - & - & + & $\mathrm{d}$ & + & + & + & + & + \\
\hline
\end{tabular}

* Signature sequence is TACGGAGACGTTT.

The others are $R$. tropici (Martínez-Romero et al., 1991), S. terangae (de Lajudie et al., 1994), $S$. arboris and S. kostiense (Nick et al., 1999). The novel species can be differentiated from E. adhaerens and related rhizobial species as shown in Table 3 . The poor growth of the isolates on monosaccharides in comparison with di- or trisaccharides and organic acids as sole carbon sources might reflect the adaptation of the isolates to the soil and rhizosphere. Antibiotic resistance in clinical bacteria has been pointed out as a serious problem and the origin and lateral transfer of antibiotic-resistance genes have been widely studied (see reviews by Nikaido, 1998; Rowe-Magnus \& Mazel, 1999), as have the mechanisms of multiple antibiotic resistance and efflux (Nikaido, 1998). The biological basis of multiple antibiotic resistance in group 11 isolates is worth investigating, since these isolates originate from sites with no known history of antibiotic use.

\section{Description of Sinorhizobium morelense sp. nov.}

Sinorhizobium morelense (mo.re.len'se. N.L. neut. adj. morelense of Morelos, the name of a state in Mexico, where the bacterium was isolated).

Gram-negative, non-spore-forming rods. Multiply by budding. Aerobic, but can grow anaerobically by denitrification. Generation time in PY broth is 1.5 $2.0 \mathrm{~h}$ at $28{ }^{\circ} \mathrm{C}$. Growth is inhibited on PY medium at $37^{\circ} \mathrm{C}$. Colonies on PY or YMA are circular, creamcoloured, semi-translucent and mucilaginous. Colonies are normally more than $2 \mathrm{~mm}$ in diameter within 3 days. A wide range of carbohydrates and amino acids is utilized as sole carbon sources for growth. However, grows less well on monosaccharides than on di- or trisaccharides. Most amino acids, except DL-alanine and urea, can be used as sole nitrogen sources for growth. Addition of biotin in defined medium can improve growth. Growth is obtained at pH 5.0-10.0. 
The most distinctive feature is multiple antibiotic resistance. The seven strains can grow in PY medium supplied with $1 \mathrm{mg}$ carbenicillin, $500 \mu \mathrm{g}$ kanamycin, $300 \mu \mathrm{g}$ erythromycin, $100 \mu \mathrm{g}$ neomycin or streptomycin or $5 \mu \mathrm{g}$ chloramphenicol or gentamicin $\mathrm{ml}^{-1}$. Sensitive to $5 \mu \mathrm{g}$ tetracycline and $20 \mu \mathrm{g}$ nalidixic acid $\mathrm{ml}^{-1}$. In litmus milk, most strains do not produce alkali and the final $\mathrm{pH}$ is $7 \cdot 0-7 \cdot 5$ after 4 weeks incubation.

The type strain is $\mathrm{Lc}^{\mathrm{T}}\left(=\mathrm{CFN} \mathrm{E} 1007^{\mathrm{T}}=\mathrm{LMG}\right.$ $21331^{\mathrm{T}}$ ). The $\mathrm{G}+\mathrm{C}$ content of this strain is $61.7 \mathrm{~mol} \%$. This strain has all the distinctive and descriptive features of the species. Its generation time in PY is $1.5 \mathrm{~h}$ at $28{ }^{\circ} \mathrm{C}$. No symbiotic plasmid is detected.

\section{ACKNOWLEDGEMENTS}

We thank Julio Martínez-Romero for performing the phylogenetic analysis of the 16S rRNA gene sequences. A.W. is grateful to the Fund for Scientific ResearchFlanders for a position as a post-doctoral research fellow.

\section{REFERENCES}

Amarger, N., Macheret, V. \& Laguerre, G. (1997). Rhizobium gallicum sp. nov. and Rhizobium giardinii sp. nov., from Phaseolus vulgaris nodules. Int J Syst Bacteriol 47, 996-1006.

Balkwill, D. L. (2002). Genus Ensifer. In Bergey's Manual of Systematic Bacteriology, 2nd edn, vol. 2. New York: Springer (in press).

Casida, L. E., Jr (1982). Ensifer adhaerens gen. nov., sp. nov.: a bacterial predator of bacteria in soil. Int J Syst Bacteriol 32, 339-345.

Chen, W. X., Yan, G. H. \& Li, J. L. (1988). Numerical taxonomic study of fast-growing soybean rhizobia and a proposal that Rhizobium fredii be assigned to Sinorhizobium gen. nov. Int J Syst Bacteriol 38, 392-397.

Chen, W. X., Tan, Z. Y., Gao, J. L., Li, Y. \& Wang, E. T. (1997). Rhizobium hainanense sp. nov., isolated from tropical legumes. Int $J$ Syst Bacteriol 47, 870-873.

Daniel, R. M., Limmer, A. W., Steele, K. W. \& Smith, I. M. (1982). Anaerobic growth, nitrate reduction and denitrification in 46 rhizobium strains. J Gen Microbiol 128, 1811-1815.

de Lajudie, P., Willems, A., Pot, B. \& 7 other authors (1994). Polyphasic taxonomy of rhizobia: emendation of the genus Sinorhizobium and description of Sinorhizobium meliloti comb. nov., Sinorhizobium saheli sp. nov., and Sinorhizobium teranga sp. nov. Int J Syst Bacteriol 44, 715-733.

de Lajudie, P., Willems, A., Nick, G. \& 9 other authors (1998a). Characterization of tropical tree rhizobia and description of Mesorhizobium plurifarium sp. nov. Int J Syst Bacteriol 48, 369-382.

de Lajudie, P., Laurent-Fulele, E., Willems, A., Torck, U., Coopman, R., Collins, M. D., Kersters, K., Dreyfus, B. \& Gillis, M. (1998b). Allorhizobium undicola gen. nov., sp. nov., nitrogen-fixing bacteria that efficiently nodulate Neptunia natans in Senegal. Int J Syst Bacteriol 48, $1277-1290$.

Dreyfus, B., Garcia, J. L. \& Gillis, M. (1988). Characterization of Azorhizobium caulinodans gen. nov., sp. nov., a stem-nodulating nitrogen-fixing bacterium isolated from Sesbania rostrata. Int $J$ Syst Bacteriol 38, 89-98.

Eardly, B. D., Materon, L. A., Smith, N. H., Johnson, D. A., Rumbaugh, M. D. \& Selander, R. K. (1990). Genetic structure of natural populations of the nitrogen-fixing bacterium Rhizobium meliloti. Appl Environ Microbiol 56, 187-194.

Ezaki, T., Hashimoto, Y. \& Yabuuchi, E. (1989). Fluorometric deoxyribonucleic acid-deoxyribonucleic acid hybridization in microdilution wells as an alternative to membrane filter hybridization in which radioisotopes are used to determine genetic relatedness among bacterial strains. Int J Syst Bacteriol 39, 224-229.
Genetics Computer Group (1995). Program Manual for the Wisconsin Package, Version 8. Madison, WI: Genetics Computer Group.

Graham, P. H., Sadowsky, M. J., Keyser, H. H. \& 8 other authors (1991). Proposed minimal standards for the description of new genera and species of root- and stem-nodulating bacteria. Int J Syst Bacteriol 41, 582-587.

Hurek, T., Wagner, B. \& Reinhold-Hurek, B. (1997). Identification of $\mathrm{N}_{2}$-fixing plant- and fungus-associated Azoarcus species by PCR-based genomic fingerprints. Appl Environ Microbiol 63, 4331-4339.

Jarvis, B. D. W., van Berkum, P., Chen, W. X., Nour, S. M., Fernandez, M. P., Cleyet-Marel, J.-C. \& Gillis, M. (1997). Transfer of Rhizobium loti, Rhizobium huakuii, Rhizobium ciceri, Rhizobium mediterraneum, and Rhizobium tianshanense to Mesorhizobium gen. nov. Int J Syst Bacteriol 47, 895-898.

Jordan, D. C. (1982). Transfer of Rhizobium japonicum Buchanan 1980 to Bradyrhizobium gen. nov., a genus of slow-growing, root nodule bacteria from leguminous plants. Int J Syst Bacteriol 32, 136-139.

Jordan, D. C. (1984). Family III. Rhizobiaceae Conn 1938, 321 ${ }^{\mathrm{AL}}$. In Bergey's Manual of Systematic Bacteriology, vol. 1, pp. 234-235. Edited by N. R. Krieg \& J. G. Holt. Baltimore: Williams \& Wilkins.

Martínez-Romero, E., Segovia, L., Mercante, F. M., Franco, A. A., Graham, P. \& Pardo, M. A. (1991). Rhizobium tropici, a novel species nodulating Phaseolus vulgaris L. beans and Leucaena sp. trees. Int J Syst Bacteriol 41, 417-426.

Mesbah, M., Premachandran, U. \& Whitman, W. B. (1989). Precise measurement of the $\mathrm{G}+\mathrm{C}$ content of deoxyribonucleic acid by highperformance liquid chromatography. Int J Syst Bacteriol 39, 159-167.

Nick, G., de Lajudie, P., Eardly, B. D., Suomalainen, S., Paulin, L., Zhang, X., Gillis, M. \& Lindström, K. (1999). Sinorhizobium arboris sp. nov. and Sinorhizobium kostiense sp. nov., isolated from leguminous trees in Sudan and Kenya. Int J Syst Bacteriol 49, 1359-1368.

Nikaido, H. (1998). Multiple antibiotic resistance and efflux. Curr Opin Microbiol 1, 516-523.

Nour, S. M., Fernandez, M. P., Normand, P. \& Cleyet-Marel, J.-C. (1994). Rhizobium ciceri sp. nov., consisting of strains that nodulate chickpeas (Cicer arietinum L.). Int J Syst Bacteriol 44, 511-522.

Page, R. D. (1996). TreeView: an application to display phylogenetic trees on personal computers. Comput Appl Biosci 12, 357-358.

Rogel, M. A., Hernández-Lucas, I., Kuykendall, L. D., Balkwill, D. L. \& Martínez-Romero, E. (2001). Nitrogen-fixing nodules with Ensifer adhaerens harboring Rhizobium tropici symbiotic plasmids. Appl Environ Microbiol 67, 3264-3268.

Rome, S., Fernandez, M. P., Brunel, B., Normand, P. \& CleyetMarel, J.-C. (1996). Sinorhizobium medicae sp. nov., isolated from annual Medicago spp. Int J Syst Bacteriol 46, 972-980.

Rowe-Magnus, D. A. \& Mazel, D. (1999). Resistance gene capture. Curr Opin Microbiol 2, 483-488.

Segovia, L., Piñero, D., Palacios, R. \& Martínez-Romero, E. (1991). Genetic structure of a soil population of nonsymbiotic Rhizobium leguminosarum. Appl Environ Microbiol 57, 426-433.

Tan, Z. Y., Wang, E. T., Peng, G. X., Zhu, M. E., Martínez-Romero, E. \& Chen, W. X. (1999). Characterization of bacteria isolated from wild legumes in the north-western regions of China. Int J Syst Bacteriol 49, 1457-1469.

Thompson, J. D., Higgins, D. G. \& Gibson, T. J. (1994). CLUSTAL W: improving the sensitivity of progressive multiple sequence alignment through sequence weighting, position-specific gap penalties and weight matrix choice. Nucleic Acids Res 22, 4673-4680.

van Berkum, P., Beyene, D., Bao, G., Campbell, T. A. \& Eardly, B. D. (1998). Rhizobium mongolense sp. nov. is one of three rhizobial genotypes identified which nodulate and form nitrogen-fixing symbioses with Medicago ruthenica [(L.) Ledebour]. Int J Syst Bacteriol 48, 13-22.

Vincent, J. M. (1970). A Manual for the Practical Study of the Root Nodule Bacteria. International Biological Programme Handbook 15. Oxford: Blackwell Scientific.

Wang, E. T. \& Martínez-Romero, E. (2000). Phylogeny of root- and stem-nodule bacteria associated with legumes. In Nitrogen Fixation in 
Bacteria: Molecular and Cellular Biology, pp. 177-186. Edited by E. W. Triplett. Wymondham, UK: Horizon Scientific Press.

Wang, E. T., van Berkum, P., Beyene, D., Sui, X. H., Dorado, O., Chen, W. X. \& Martínez-Romero, E. (1998). Rhizobium huautlense sp. nov., a symbiont of Sesbania herbacea that has a close phylogenetic relationship with Rhizobium galegae. Int J Syst Bacteriol 48, 687-699.

Wang, E. T., van Berkum, P., Sui, X. H., Beyene, D., Chen, W. X. \& Martínez-Romero, E. (1999a). Diversity of rhizobia associated with Amorpha fruticosa isolated from Chinese soils and description of Mesorhizobium amorphae sp. nov. Int J Syst Bacteriol 49, 51-65.

Wang, E. T., Martínez-Romero, J. \& Martínez-Romero, E. (1999b).
Genetic diversity of rhizobia from Leucaena leucocephala nodules in Mexican soils. Mol Ecol 8, 711-724.

Ward, D. M. (1998). A natural species concept for prokaryotes. Curr Opin Microbiol 1, 271-277.

Wayne, L. G., Brenner, D. J., Colwell, R. R. \& 9 other authors (1987). Report of the ad hoc committee on reconciliation of approaches to bacterial systematics. Int J Syst Bacteriol 37, 463-464.

Willems, A., Doignon-Bourcier, F., Goris, J., Coopman, R., de Lajudie, P., De Vos, P. \& Gillis, M. (2001). DNA-DNA hybridization study of Bradyrhizobium strains. Int J Syst Evol Microbiol 51, $1315-1322$. 